\title{
T cell immunity and caregiving stress in young and older caregivers
}

\author{
Ana Vitlic ${ }^{1,2}$, Janet M. Lord ${ }^{2,3}$, Wiebke Arlt ${ }^{4}$, Christopher Oliver ${ }^{5}$, Anna C. Phillips ${ }^{12^{*}}$ \\ 1 School of Sport, Exercise and Rehabilitation Sciences, University of Birmingham, Edgbaston, Birmingham, West Midlands, UK \\ 2 MRC-Arthritis Research UK Centre for Musculoskeletal Ageing Research, University of Birmingham, Edgbaston, Birmingham, West \\ Midlands, UK 3 School of Immunity and Infection, University of Birmingham, Edgbaston, Birmingham, West Midlands, UK 4 Centre for \\ Endocrinology, Diabetes and Metabolism (CEDAM), University of Birmingham, Edgbaston, Birmingham, West Midlands, UK 5 School \\ of Psychology, University of Birmingham, Edgbaston, Birmingham, West Midlands, UK
}

\begin{abstract}
Background: The present study aimed to examine the impact of caregiving stress and aging on parameters of $\mathrm{T}$ cell immunity using caregivers and controls across two age cohorts.

Methods: Seventy-nine young and older caregivers (parents of children with developmental disabilities and spousal dementia caregivers, respectively) were compared to 76 non-caregiving controls. Participants completed questionnaires to provide information about socio-demographics, health behaviour, psychosocial and caregiving variables, and provided a blood sample. $\mathrm{T}$ cell senescence and exhaustion markers, thymic output, and serum CMV antibody titre were assessed.

Results: Despite greater psychological morbidity (greater depression, anxiety, perceived stress) than controls, caregivers showed robust immunity for most $\mathrm{T}$ cell parameters with the exception of KLRG-1 (marker involved in $\mathrm{T}$ cell senescence pathway).

Conclusions: A higher percentage of $\mathrm{KLRG}^{+} \mathrm{T}$ cells in caregivers could explain the poorer vaccination response that has previously been reported in this group. These data also suggest that the impact of caregiving
\end{abstract} per se on immunity is not uniform.

Citation: Vitlic A, Lord JM, Arlt W, Oliver C, Phillips AC (2015) T cell immunity and caregiving stress in young and older caregivers. Healthy Aging Research 4:15. doi:10.12715/har.2015.4.15

Received: December 18, 2014; Accepted: January 28, 2015; Published: February 23, 2015.

Copyright: (C) 2015 Vitlic et al. This is an open access article distributed under the terms of the Creative Commons Attribution License, which permits unrestricted use, distribution, and reproduction in any medium, provided the original work is properly cited.

Competing interests: The authors have declared that no competing interests exist.

Sources of funding: The study was funded by the University of Birmingham and an EU FP7 Marie Curie Initial Training Network (PITN-2009-238665; NINA).

*Email: A.C.Phillips@bham.ac.uk

\section{Introduction}

Chronic stress (e.g. that caused by caregiving or bereavement) has been reported to have numerous adverse effects on adaptive immunity [1]. The immune system correlates of the negative effects of stress include reduced vaccination response [2], poorer latent virus control [3] and thymic involution indicated by reduced output of naive T cells [4].

Adaptive immunity undergoes dramatic changes during aging; this is termed immunosenescence and includes decreased naive $\mathrm{T}$ cell production [5] and a shift in numbers of naive $\mathrm{T}$ cells towards longer lived memory $\mathrm{T}$ cells - in particular $\mathrm{CD} 8^{+}$cells - as the memory $\mathrm{T}$ cell pool expands to maintain homeostasis [6]. Quantification of thymic output and naive $\mathrm{T}$ cell production is achieved by counting the number of cells expressing $\mathrm{T}$ cell receptor excision circles (TREC); stable extrachromosomal DNA fragments created during $\mathrm{T}$ cell receptor (TCR) formation [7].

In addition, aging is accompanied by many phenotypic and functional alterations in $\mathrm{T}$ cell subsets. 
For example, expression of CD28 antigen, a costimulatory molecule necessary for $\mathrm{T}$ cell activation, is decreased during aging [8], with implications for longevity of vaccination responses and resistance to latent infections. Further, an increase in the subsets of senescent $\mathrm{CD} 28^{-} \mathrm{CD} 57^{+}$lymphocytes with normal aging has been noted [9]. CD57 is present on terminally differentiated $\mathrm{T}$ lymphocytes; it is considered to be a marker contributing to $\mathrm{T}$ cell senescence [10] and is indicative of increased activation-induced apoptosis [11]. Programmed celldeath-1 (PD-1), a receptor that plays an inhibitory role during $\mathrm{T}$ cell activation and is important in $\mathrm{T}$ cell exhaustion [12] is also present more frequently on aged $\mathrm{T}$ lymphocytes [13]. Finally, another inhibitory receptor commonly considered a marker of $\mathrm{T}$ cell senescence, is co-inhibitory cadherin killer-cell lectinlike receptor G1 (KLRG-1) [14], which shows increased expression in older donors [15]. Interestingly, it has been shown that blockade of KLRG-1 leads to restoration of proliferative function by a mechanism involving the phosphorylation and activation of Akt protein kinase, suggesting KLRG-1 regulates both exhaustion and senescence-related pathways [16]. Implications of these changes in cell senescence and cell exhaustion are a negative impact on the functional capacity of memory $\mathrm{T}$ cells, the integrity of the immune response overall, and thus resistance to infection [16].

Another important contributor to immunosenescence is Cytomegalovirus (CMV) infection [17], a latent Herpes virus with the ability to remain silent until inflammatory factors and weakened immune surveillance trigger its activation. This virus is believed to direct the restructuring of lymphoid subsets in the periphery, seen as an increase in effector memory $\mathrm{T}$ cells and a reduction in the naive $\mathrm{T}$ cells in those who are CMV-seropositive [18]. Consequently, the presence of CMV leads to the accumulation of $\mathrm{T}$ cells with a senescent and exhausted profile, namely a $\mathrm{CD} 28^{-} \mathrm{CD} 57^{+} \mathrm{KLRG}-1^{+}$ phenotype.

Until recently, there has been a consensus that caregivers, regardless of their age, have poorer immunity than non-caregivers [2, 19-22]. However, we have recently demonstrated that caregivers, both young and older, displayed robust neutrophil function compared to matched controls. Indeed, neutrophil function was only diminished in caregivers with higher psychological morbidity (unpublished data). The present analysis extends our previous observations with respect to innate immunity by examining the associations between caregiving stress, aging, and $\mathrm{T}$ cell immunity using four different participant groups: younger parental caregivers of children with developmental disabilities and age- and sex-matched parental controls of typically developing children; older spousal dementia caregivers, and matched healthy older adults. This four-group comparison allows us to examine the effects of caregiving stress on $\mathrm{T}$ cell immunity with and without aging.

Focussing on $\mathrm{T}$ cell immunity, this study examined TREC expression as a marker of thymic output, and expression of markers of the senescent and exhaustion profiles of $T$ cells. It also aimed to determine whether any psychosocial or caregiving-specific variables, e.g. depression, were related to greater immunosenescence within the caregiver group. It was expected that caregivers, particularly older caregivers, and those with higher psychological morbidity would show the greatest immunosenescence. Finally, by measuring anti-CMV antibody titre, the study aimed to ascertain if any group differences were driven by latent viral infection.

\section{Methods}

\section{Participants}

Thirty-nine young parental caregivers and 34 age- and sex-matched control parents, and 40 older spousal caregivers and 42 matched controls were recruited. Inclusion criteria for the younger group were that they should have a child living at home aged between 3 and 18 years. Our sample included parents of children with Smith-Magenis (28\%), Fragile X syndrome (54\%), and Cornelia de Lange (18\%) syndromes; these were recruited via syndrome group events. Parents in the control group had typically developing children and were recruited via local advertisements. Older caregivers were aged $60+$ years and full-time carers of a spouse/partner with diagnosed dementia; these participants were recruited via UK National Health Service (NHS) Trusts. Healthy participants in the older control group were recruited through the 
Birmingham $\quad 1000 \quad$ Elders group (http://www.birmingham.ac.uk/research/activity/mds/ centres/healthy-ageing/elders.aspx).

Potential participants were excluded from any group if they were taking immunosuppressive drugs, had a chronic immune-related disease (e.g. cancer, diabetes, rheumatoid arthritis), or if they were pregnant.

\section{Study design and procedure}

This was a cross-sectional study, with a one-off session for the completion of the questionnaire and provision of a blood sample. Informed written consent was obtained from all participants, and the study was approved by the local NHS Research Ethics Committee.

\section{Questionnaires}

Health behaviours were assessed using a questionnaire adapted from the Whitehall II study [23]. The Hospital Anxiety and Depression Scale (HADS) [24], Perceived Stress Scale (PSS) [25], and Zarit Burden Interview (ZBI) [26], were used to determine psychological morbidity, while social support availability was examined using the Support Function Scale (SFS) [27]. Finally, children's challenging behaviour was assessed through the Strengths and Difficulties Questionnaire (SDQ) [28], while the Pearlin Problematic Behaviour (PPB) [29] subscale was administered to older caregivers in order to report on the frequency of dementia-related behaviours in their spouse/partner.

\section{Blood sampling and assays}

\section{Blood sampling}

Venous blood was collected into heparinised tubes, pre-prandially between 9 and 11 a.m. Peripheral blood mononuclear cells (PBMCs) were isolated by standard density gradient centrifugation using Ficoll-Paque ${ }^{\mathrm{TM}}$ PLUS (GE Healthcare, Upsala Sweden), aliquoted and stored in a freezing medium of inactivated foetal calf serum (Sera Laboratories International, Sussex, UK) and $10 \%(\mathrm{v} / \mathrm{v})$ dimethyl sulphoxide (DMSO), to allow recovery of functional frozen PBMCs.
Immunostaining for senescent and exhausted profile of T cells

Isolated PBMCs were stained with a combination of fluorochrome-conjugated anti-human antibodies and consequent multicolour flow cytometry analysis using a CyAn $_{\mathrm{ADP}}^{\mathrm{TM}}$ cytometer (Dako, Cambridgeshire, UK). Appropriate isotope controls were used to set the gates and compensation was conducted electronically (using Summit software) before each experiment using single stained cells. The specific anti-human antibodies used for staining can be obtained from the authors on request. Cells were washed and re-suspended in phosphate buffered saline with bovine serum albumin (PBS/BSA) for flow cytometry. At least 15,000 events were acquired within the lymphocyte gate for each sample. Further phenotyping was conducted on $\mathrm{CD}^{+}{ }^{+} \mathrm{CD} 4^{+}$and $\mathrm{CD}^{+} \mathrm{CD}^{+}$cells. $\mathrm{T}$ cell senescent profiles were characterised by the absence of CD28 and/or the presence of CD57, and the exhaustion profile was assessed by PD-1 expression, in $\mathrm{CD} 4^{+}$and $\mathrm{CD}^{+}$T-cells separately. KLRG-1 ${ }^{+} \mathrm{T}$ cells were separately examined, as they are involved in both senescence and exhaustion. Data analyses were conducted using Summit v4.3 software (Dako, USA) and are presented as the percentage of antigen-positive cells.

\section{Thymic output analysis}

Thymic output was assessed via $\mathrm{T}$ cell Receptor Excision Circles (TREC) analysis, where a low TREC expression ratio indicates lower thymic output of naive T-cells [30,31]. DNA was isolated from PBMCs using the QIAamp DNA Blood Mini Kit (Quiagen, UK) and eluted in $50 \mu 1$ of DNA elution buffer. DNA concentration and purity was subsequently measured using a NanoDrop ${ }^{\mathrm{TM}}$ spectrophotometer and only those samples with a 260/280 and 260/230 ratio above 1.8 were used. Aliquots of 200ng of DNA were used for quantitative polymerase chain reaction (qPCR) analysis. Real-time PCR was performed on a Real Time PCR Roche LC480 sw1.5 machine using fluorescent primer- and probe-based chemistry (TaqMan probe). Reaction volume consisted of forward and reverse primers in a final concentration of $0.5 \mu \mathrm{M}$, and probes in a final concentration of $0.2 \mu \mathrm{M}$ for both TREC and the control gene, $2 \mathrm{x}$ TaqMan Master Mix from LightCycler 480 Probes Master Mix 
(Roche, UK) in a final reaction volume of $20 \mu \mathrm{l}$ per sample made using nuclease-free water (Roche, UK). The primer sequences for TREC were 5'CACATCCCTTTCAACCATGCT' for forward, and 5'-GCCAGCTGCAGGGTTTAGG-3' for the reverse primer.

\section{ACACCTCTGGTTTTTGTAAAGGTGCCCACT}

was used as the fluorescent sequence-specific probe. Primers were dissolved in the quantity of provided buffer to yield $100 \mathrm{pmol} / \mu 1$, then aliquoted and stored at $-20^{\circ} \mathrm{C}$. For normalisation, a referent gene representing the constant region of the $\mathrm{T}$ cell receptor was used: 5'-CCTGATCCTCTTGTCCCACAG-3' for the forward primer, and 5'GGATTTAGAGTCTCTCAGCTGGTACA-3' for the reverse primer, as well as a 5'ATCCAGAACCCTGACCCTGCCG-3' probe. Samples were run in triplicate and an average $\mathrm{Ct}$ value was calculated for both TREC and the reference gene. Rather than calculating the exact number of copies of TREC per number of $\mathrm{T}$ cells for every sample, the Pfaffl formula [32] was used to quantify TREC by comparing TREC status to the calibrator. The lower the expression ratio, the higher the decrease of the TREC gene in the test sample when compared to the calibrator.

\section{CMV serum antibody titre}

A standardised CMV ELISA developed by the Antiviral Immunology Laboratory, Cancer Sciences, University of Birmingham was used as previously reported [33]. The standard curve measured up to 1000 arbitrary units of $\mathrm{IgG}$, and those with more than 10 units were considered CMV-positive.

\section{Statistical analyses}

We aimed to recruit enough participants to detect a medium effect size $(\mathrm{f}=0.29)$. This required an overall sample size of 134, thus recruitment of 35 participants to each group. Where immune data were skewed, values were log-transformed. The main effects of age and caregiving status, as well as caregiving $\mathrm{x}$ age interactions, were examined using analysis of variance (ANOVA) tests, with partial $\eta^{2}$ as the effect size. Demographic information, health behaviour variables, and numbers of $\mathrm{CD}^{+}$cells that were significantly different between the groups (in chi-square or ANOVA), were controlled for by analysis of covariance (ANCOVA) tests. Analyses were re-run using CMV status as a covariate to ascertain if any effects were driven by CMV infection. CMV seropositive participants were divided into two groups using a median split of anti-CMV antibody titre to examine associations with parameters of $\mathrm{T}$ cell immunity. Correlations were used within caregivers to test whether psychosocial and caregiving variables were associated with immune outcomes.

\section{Results}

\section{Demographic information, health behaviour and psychosocial characteristics}

Descriptive statistics for demographic and health behaviour variables for each group are presented in Table 1. Caregivers and controls were comparable for all demographics and health behaviours, with the exception of young caregivers, who were more likely to be white and to drink alcohol daily compared to control parents. Older participants in the control groups tended to be more active than caregivers. Table 1 shows that caregivers reported higher depression, anxiety, perceived stress, and lower social support than non-caregivers. Caregiving burden was also higher in younger caregivers than in controls, while older caregivers scored high on this scale according to the reported cut-off of 17 [26]. For problematic behaviour of care-recipients, younger parental caregivers reported more problems than control parents, while older spousal dementia caregivers reported higher scores on the Pearlin scale than those previously reported by caregivers [34].

\section{Immunostaining for exhausted and senescent profile of $T$ cells}

For $\mathrm{CD}^{+}$cell number (representative flow cytometry plot shown in Figure 1A), there was a main effect of caregiving $\left(\mathrm{F}(1,140)=7.97, p=0.005, \eta^{2}=0.054\right)$, such that caregivers had higher numbers (Figure 1B). Therefore, $\mathrm{CD}^{+}$cell number was a covariate in subsequent analyses. 
Table 1. Demographic characteristics, health behaviours and psychosocial variables of each group

\begin{tabular}{|c|c|c|c|c|c|c|}
\hline & \multicolumn{3}{|c|}{ Young } & \multicolumn{3}{|c|}{ Older } \\
\hline & $\begin{array}{c}\text { Caregivers } \\
\quad(\mathrm{n}=39)\end{array}$ & $\begin{array}{c}\text { Controls } \\
(n=34)\end{array}$ & & $\begin{array}{c}\text { Caregivers } \\
(\mathrm{n}=40)\end{array}$ & $\begin{array}{l}\text { Controls } \\
(\mathrm{n}=42)\end{array}$ & \\
\hline & \multicolumn{2}{|c|}{ n (\%)/Mean (SD) } & $p$ & \multicolumn{2}{|c|}{$\mathrm{N}(\%) /$ Mean $(\mathrm{SD})$} & $p$ \\
\hline Age (years) & $38.7(4.78)$ & $40.1(5.44)$ & 0.26 & $69.3(5.81)$ & $72.4(5.42)$ & 0.06 \\
\hline Age of child/spouse (years) & $7.6(3.63)$ & $7.2(4.54)$ & 0.66 & $72.3(8.06)$ & $73.1(6.04)$ & 0.63 \\
\hline Gender (female) & $25(64)$ & $21(62)$ & 0.84 & $26(65)$ & $19(45)$ & 0.07 \\
\hline Marital status (partnered) & $33(89)$ & $30(88)$ & 0.90 & $40(100)$ & $42(100)$ & - \\
\hline Ethnicity (Caucasian) & $36(97)$ & $27(79)$ & 0.02 & $38(97)$ & $39(93)$ & 0.33 \\
\hline Occupational status (non-manual) & $30(88)$ & $31(94)$ & 0.41 & $22(63)$ & $32(80)$ & 0.10 \\
\hline In full-time work & $15(48)$ & $19(63)$ & 0.24 & $3(8)$ & $1(4)$ & 0.53 \\
\hline No chronic illness & $35(95)$ & $29(85)$ & 0.19 & $21(55)$ & $17(42)$ & 0.26 \\
\hline Taking medications & $2(6)$ & $7(21)$ & 0.06 & $33(80)$ & $29(74)$ & 0.51 \\
\hline Alcohol intake (daily + ) & $10(27)$ & $1(3)$ & 0.01 & $10(28)$ & $12(30)$ & 0.83 \\
\hline Smokers & (14) & $2(6)$ & 0.30 & $1(3)$ & $3(7)$ & 0.36 \\
\hline Hours of sleep ( $>7$ hours) & $6(17)$ & $3(9)$ & 0.38 & 7 (19) & $8(21)$ & 0.86 \\
\hline Body Mass Index & $25.8(4.65)$ & $24.5(3.58)$ & 0.21 & $26.3(3.08)$ & $26.1(4.37)$ & 0.82 \\
\hline Exercise score & $5.2(4.30)$ & $6.4(5.44)$ & 0.29 & $3.5(3.16)$ & $5.2(3.71)$ & 0.04 \\
\hline HADS anxiety score & $10.4(3.85)$ & $6.4(2.85)$ & $<0.001$ & $7.7(4.96)$ & $4.1(3.93)$ & $<0.001$ \\
\hline HADS depression score & $8.5(3.18)$ & $4.2(3.67)$ & $<0.001$ & $6.0(3.94)$ & $2.8(2.61)$ & $<0.001$ \\
\hline Perceived stress score & $30.2(5.68)$ & $23.5(6.59)$ & $<0.001$ & $24.0(8.21)$ & $16.4(7.83)$ & $<0.001$ \\
\hline Social support score (SFS) & $31.6(7.17)$ & $38.6(9.62)$ & 0.001 & $33.6(11.18)$ & - & - \\
\hline Caregiver burden score & $26.0(7.82)$ & $13.7(6.69)$ & $<0.001$ & $21.0(8.62)$ & - & - \\
\hline Child behaviour problems & $19.6(4.62)$ & $7.2(3.99)$ & $<0.001$ & - & - & - \\
\hline Pearlin problem behaviours & - & - & - & $22.9(5.89)$ & - & - \\
\hline CMV seropositive & $13(34)$ & $19(59)$ & 0.04 & $24(63)$ & $27(64)$ & 0.92 \\
\hline CMV antibody titre & $82.2(178.75)$ & $158.7(223.34)$ & 0.63 & $200.2(261.08)$ & $169.9(190.07)$ & 0.45 \\
\hline
\end{tabular}

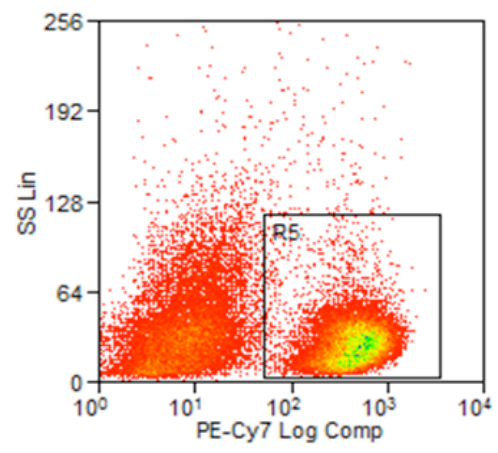

CD 3

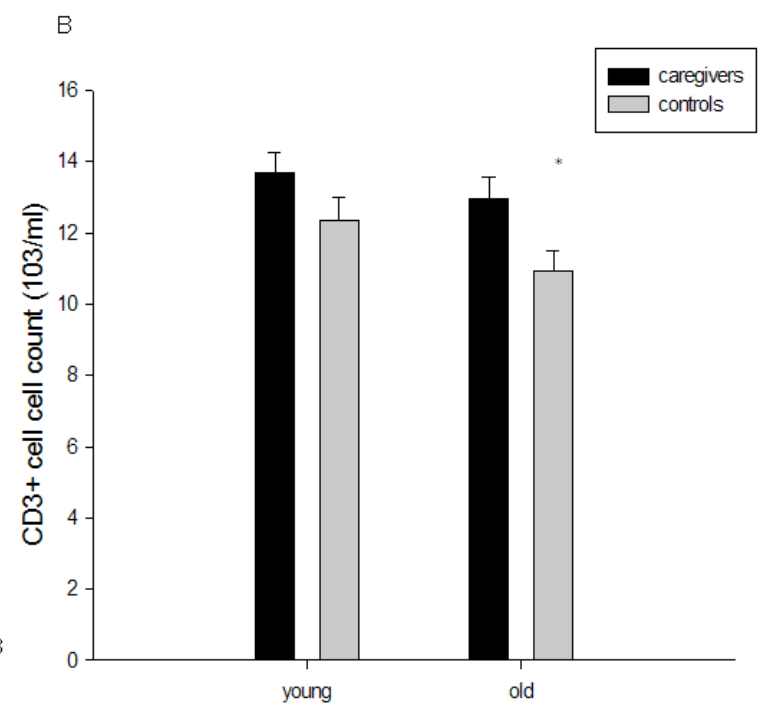

Figure 1. $\mathrm{CD}^{+}$cell count old $(n=40)$ and young $(n=31)$ controls. 


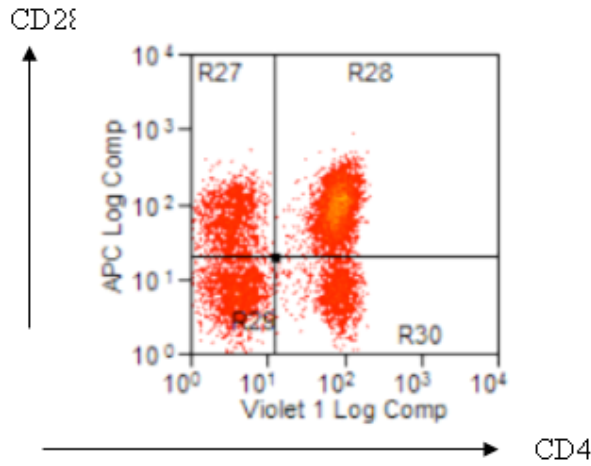

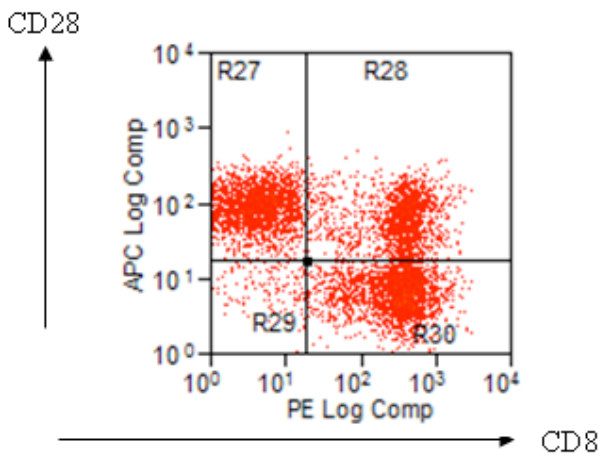

П
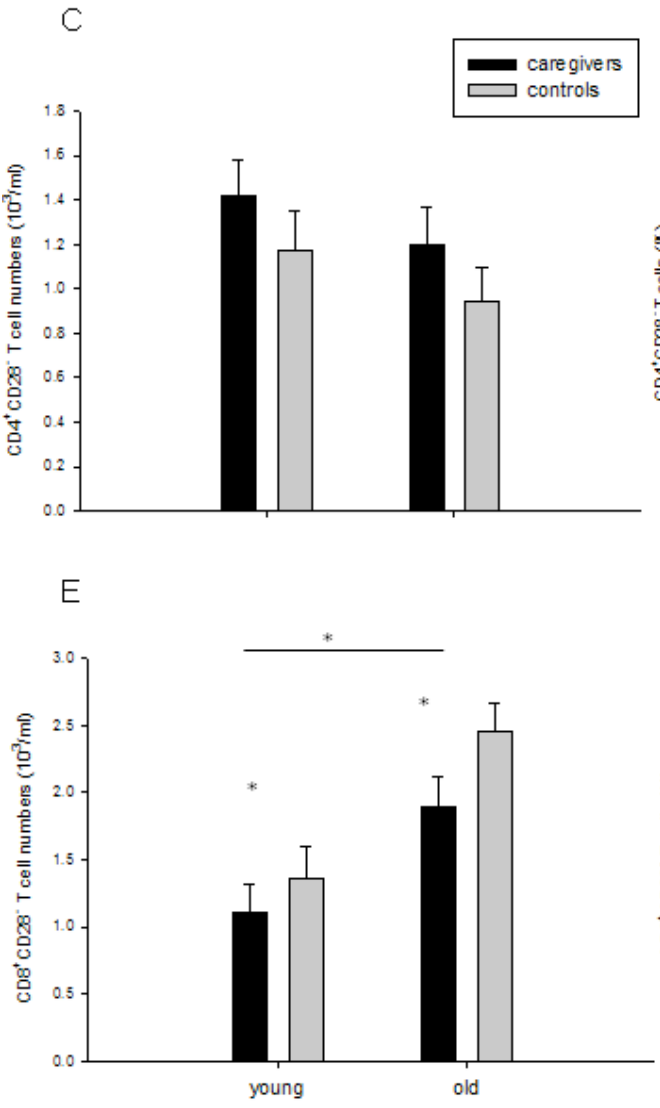

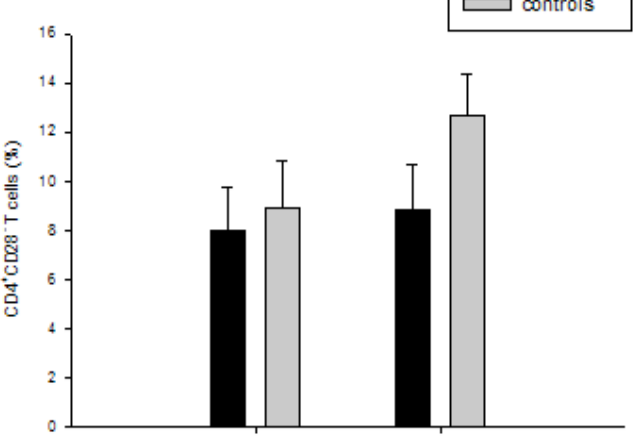

$\mathrm{F}$

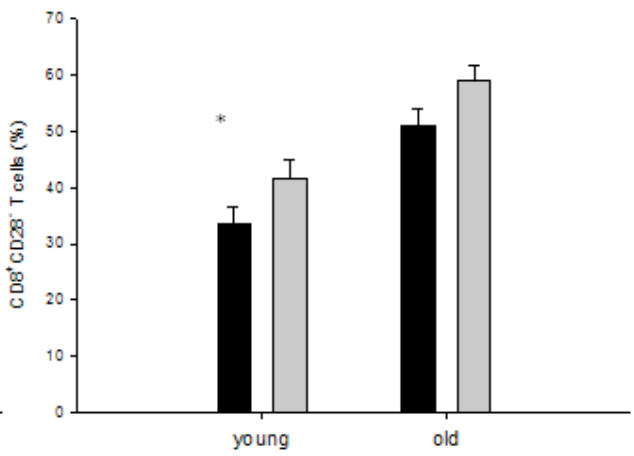

Figure 2. CD3+ cells not expressing the CD28 marker

Representative flow cytometric plots demonstrating the gating pattern used for identification of: A) CD4+CD28- and CD4+CD28+ cells within a CD3+ cell population of lymphocytes; B) CD8+CD28- and CD8+CD28+cells within a CD3+ cell population of lymphocytes. C) Absolute numbers of $\mathrm{CD} 4+\mathrm{CD} 28$ - $\mathrm{T}$ cells in old $(\mathrm{n}=35)$ and young $(\mathrm{n}=38)$ caregivers, and old $(\mathrm{n}=40)$ and young $(\mathrm{n}=31)$ controls presented in $103 / \mathrm{ml}$. D) Corresponding percentages of these cells in old $(\mathrm{n}=35)$ and young $(\mathrm{n}=38)$ caregivers, and old $(n=40)$ and young $(n=31)$ controls. E and F) Absolute numbers (presented in $103 / \mathrm{ml}$ ) and percentage, respectively, of CD8 + CD28- T cells in old $(n=35)$ and young $(n=38)$ caregivers, and old $(n=40)$ and young $(n=31)$ controls. Data are presented as mean, and standard error of the mean (SEM), rather than their log values used in the analyses. * indicates $\mathrm{p}<0.05$. 


\section{$\mathrm{CD}^{+} \mathrm{T}$ cells expressing/not expressing the CD28 co- stimulatory molecule}

Figures $2 \mathrm{~A}$ and $\mathrm{B}$ show representative flow cytometry plots demonstrating gating for identifying CD28positive and negative cells. There were no main effects of age or caregiving, or a caregiving $\mathrm{x}$ age interaction effect for $\mathrm{CD} 4^{+} \mathrm{CD} 28^{-} \mathrm{T}$ cell count (Figure $2 \mathrm{C})$. Subsequent analyses with covariate adjustment confirmed this. For the percentage of $\mathrm{CD} 4^{+} \mathrm{CD} 28^{-} \mathrm{T}$ cells, there were similarly no effects (Figure 2D).

For $\mathrm{CD} 8^{+} \mathrm{CD} 28^{-} \mathrm{T}$ cell counts there was a main effect of age $\left(F(1,140)=12.69, p=0.001, \eta^{2}=0.083\right)$ such that older participants had higher numbers of these cells, but no main effect of caregiving, nor interaction effect (Figure 2E). Covariate analyses confirmed the main effect of age $(p<0.001)$, and revealed a main effect of caregiving, such that - unexpectedly - caregivers had lower numbers of these cells than controls $(p=0.03)$. For $\mathrm{CD} 8^{+} \mathrm{CD} 28^{-} \mathrm{T}$ cell percentage there was a main effect of age $\left(\mathrm{F}(1,140)=22.94, p<0.001, \eta^{2}=0.141\right)$ and caregiving $\left(\mathrm{F}(1,140)=5.27, p=0.02, \eta^{2}=0.036\right)$ such that participants in the older group and controls had a higher percentage of $\mathrm{CD}^{+} \mathrm{CD} 28^{-}$cells. Pairwise comparisons revealed that the difference within the younger group was the main driver of the caregiving effect (see Figure 2F). Covariate analyses confirmed the main effects of age $(p<0.001)$ and caregiving $(p=0.02)$.

For the numbers of $\mathrm{CD}^{+} \mathrm{CD}^{+}$cells expressing $\mathrm{CD} 28$, there was no main effect of age, but there was a main effect of caregiving $(\mathrm{F}(1,140)=11.55, p=0.001$, $\left.\eta^{2}=0.076\right)$ and a caregiving $x$ age interaction effect $\left(\mathrm{F}(1,140)=4.63, p=0.03, \eta^{2}=0.032\right)$ (see Figure $\left.3 \mathrm{~A}\right)$. However, covariate adjustment confirmed only the caregiving $\mathrm{x}$ age interaction effect $(p=0.001)$, such that older caregivers had highest numbers. For the percentage of these cells, there were no significant effects (Figure 3B).

For $\mathrm{CD} 8^{+} \mathrm{CD} 28^{+}$cell numbers, there was a main effect of age $\left(\mathrm{F}(1,140)=49.79, \quad p<0.001, \eta^{2}=0.262\right)$ and caregiving $\left(\mathrm{F}(1,140)=6.61, p=0.01, \eta^{2}=0.045\right)$, such that younger participants and caregivers had more of these cells, but no caregiving $\mathrm{x}$ age interaction (Figure $3 \mathrm{C})$. Covariate adjustment revealed only the main effect of age $(p<0.001)$. For the percentage of these cells, again main effects of age $(\mathrm{F}(1,140)=35.35$, $\left.p<0.001, \eta^{2}=0.202\right)$ and caregiving $(\mathrm{F}(1,140)=10.68$, $p=0.001, \eta^{2}=0.071$ were observed, such that younger adults and caregivers had a higher percentage of these cells (Figure 3D). ANCOVA confirmed the effects of age and caregiving ( $p=0.001$ and 0.03 ).

\section{CD3+ cells expressing the CD57 marker of $T$ cell senescence}

For the $\mathrm{CD} 4^{+} \mathrm{CD} 57^{+} \mathrm{T}$ cell count (flow cytometry identification shown in Figure 4A), there was a main effect of age $\left(\mathrm{F}(1,140)=11.86, p=0.001, \eta^{2}=0.078\right)$ such that older adults had higher numbers (Figure $4 C)$; ANCOVA confirmed this $(p=0.001)$. For the $\mathrm{CD} 4{ }^{+} \mathrm{CD} 57^{+} \mathrm{T}$ cell percentage, there was a main effect of age $\left(\mathrm{F}(1,140)=13.56, \quad p<0.001, \eta^{2}=0.088\right)$ and caregiving $\left(\mathrm{F}(1,140)=5.50, p=0.02, \eta^{2}=0.038\right)$ such that older participants and controls had a higher frequency of $\mathrm{CD} 4{ }^{+} \mathrm{CD} 57^{+}$cells (Figure 4D). Covariate analyses confirmed only the main effect of age $(p=0.003)$.

For $\mathrm{CD} 8^{+} \mathrm{CD} 57^{+} \mathrm{T}$ cell numbers (flow cytometry identification shown in Figure 4B), there was a main effect of age $\left(\mathrm{F}(1,140)=12.69, p=0.001, \eta^{2}=0.083\right)$ such that participants from the older cohort had higher numbers of these cells, but no other significant effects. Covariate analyses confirmed the age effect, and revealed a main effect of caregiving ( $p=0.001$ and 0.03 , respectively) (Figure 4E). For the percentage of these cells, there was a main effect of age $\left(\mathrm{F}(1,140)=38.70, p<0.001, \eta^{2}=0.281\right)$ such that older participants had a higher percentage of $\mathrm{CD} 8^{+} \mathrm{CD} 57^{+}$ cells, confirmed after covariate adjustment $(p<0.001)$, but there were no other significant effects (Figure 4F).

\section{KLRG-1+T cells}

For $\mathrm{CD} 4^{+} \mathrm{KLRG}^{+}{ }^{+} \mathrm{T}$ cell numbers (flow cytometry identification shown in Figure 5A), there was only a main effect of caregiving $(\mathrm{F}(1,140)=6.69, p=0.01$, $\left.\eta^{2}=0.047\right)$ such that caregivers overall had a higher percentage of cells expressing this marker (Figure $5 \mathrm{C})$; this was confirmed after covariate adjustment $(p=0.04)$. There were no significant effects for the percentage of $\mathrm{CD}^{+}{ }^{\mathrm{KLRG}} 1^{+} \mathrm{T}$ cells (Figure 5D), but after covariate adjustment a main effect of caregiving emerged $(p=0.03)$ such that caregivers had a higher percentage of these cells. 


$$
\text { A }
$$

B
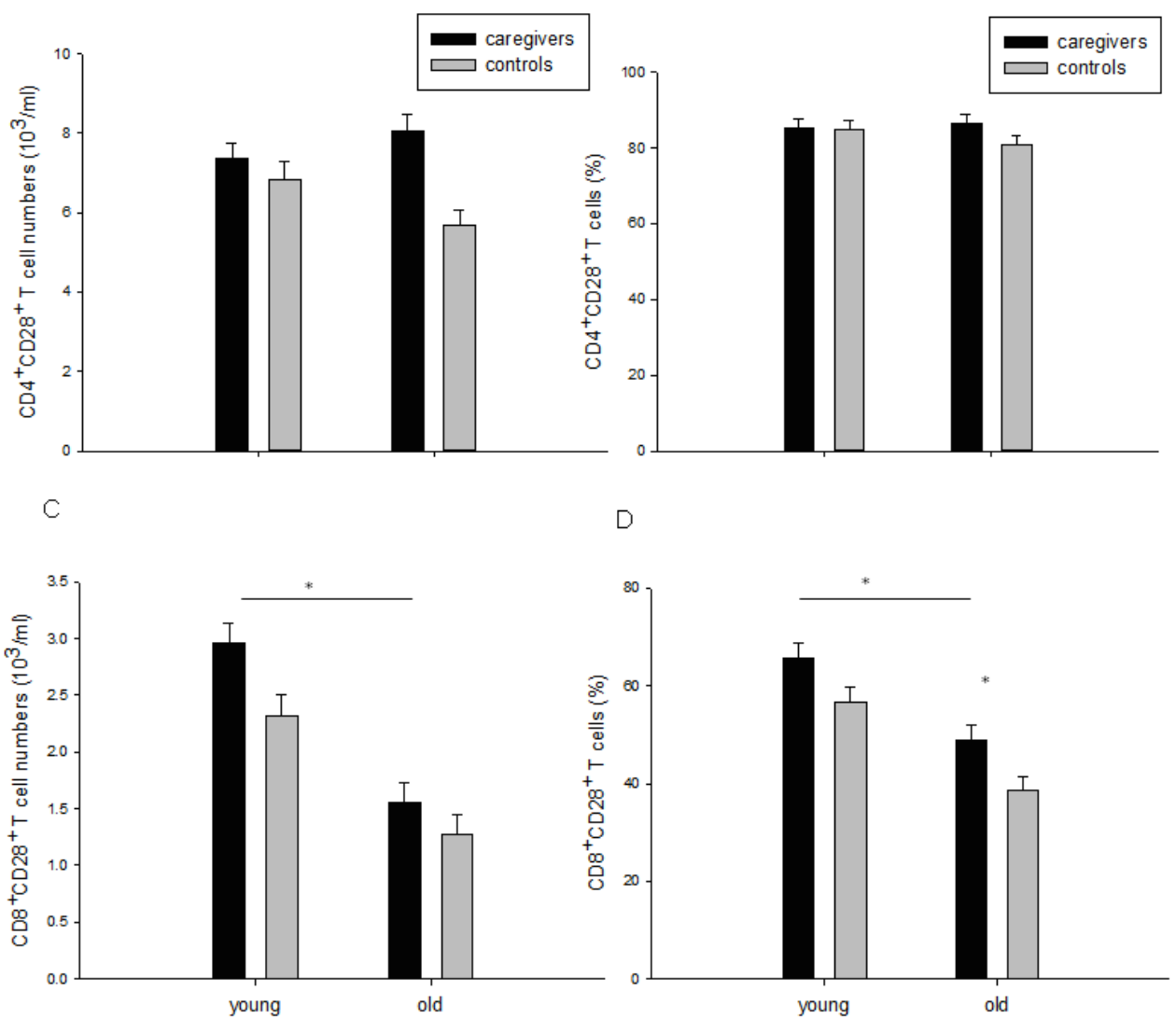

Figure 3. CD3+ cells expressing the CD28 marker

CD4 + CD28 + T cells in old $(n=35)$ and young $(n=38)$ caregivers, and old $(n=40)$ and young $(n=31)$ controls presented in: A) absolute numbers $(103 / \mathrm{ml})$, and B) percentages. $C D 8+C D 28-T$ cells in old $(n=35)$ and young $(n=38)$ caregivers, and old $(n=40)$ and young $(n=31)$ controls presented as: C) absolute numbers $(103 / \mathrm{ml})$, and D) percentages. Data are presented as mean and SEM. * indicates p $<0.05$

For $\mathrm{CD}^{+} \mathrm{KLRG}^{+} \mathrm{T}$ cell numbers (flow cytometry identification shown in Figure 5B), there was only a main effect of caregiving $(\mathrm{F}(1,140)=6.07, p=0.02$, $\eta^{2}=0.042$ ) such that caregivers overall had a higher numbers of these cells. After covariate adjustment, a main effect of age emerged $(p=0.03)$ and the effect of caregiving was confirmed $(p=0.04)$ (Figure $5 \mathrm{E}$ ). For frequency of these cells, there was a main effect of age $\left(\mathrm{F}(1,140)=5.93, p=0.02, \eta^{2}=0.041\right.$, and caregiving $\left(\mathrm{F}(1,140)=5.36, p=0.02, \eta^{2}=0.037\right)$, with older adults and caregivers having a higher percentage, but no caregiving $\mathrm{x}$ age interaction effect (Figure 5F).

Covariate adjustment confirmed these effects ( $p=0.01$ and 0.02).

\section{T cells expressing the PD-1 marker of exhaustion}

For $\mathrm{CD}^{+}{ }^{\mathrm{PD}} 1^{+} \mathrm{T}$ cell count (flow cytometry identification shown in Figure 6A), there was a main effect of age $\left(\mathrm{F}(1,140)=16.01, p<0.001, \eta^{2}=0.103\right)$ such that the older group had more of these cells, and a caregiving $\mathrm{x}$ age interaction effect $(\mathrm{F}(1,140)=6.30$, $p=0.01, \eta^{2}=0.043$ ) such that older caregivers had the highest number of these cells; covariate analyses confirmed these effects $(p<0.001$ and 0.04) (Figure $6 \mathrm{C})$. For the percentage, there was only a main effect of age $\left(\mathrm{F}(1,140)=22.45, p<0.001, \eta^{2}=0.138\right)$ such that younger participants had a lower percentage of $\mathrm{T}$ cells expressing this marker of exhaustion (Figure 6D); covariate analysis confirmed this $(p<0.001)$. 
A

CD 57
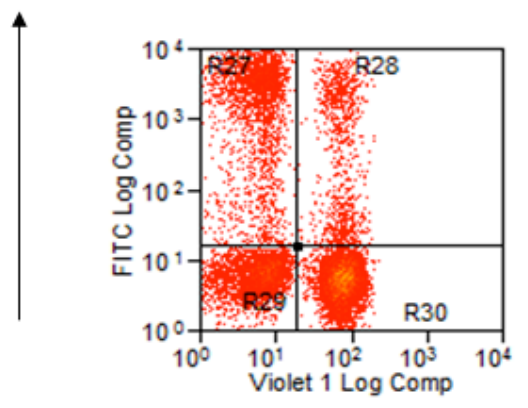

B

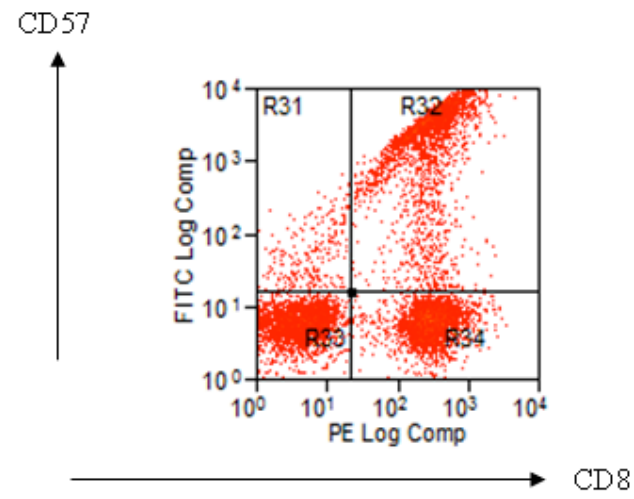

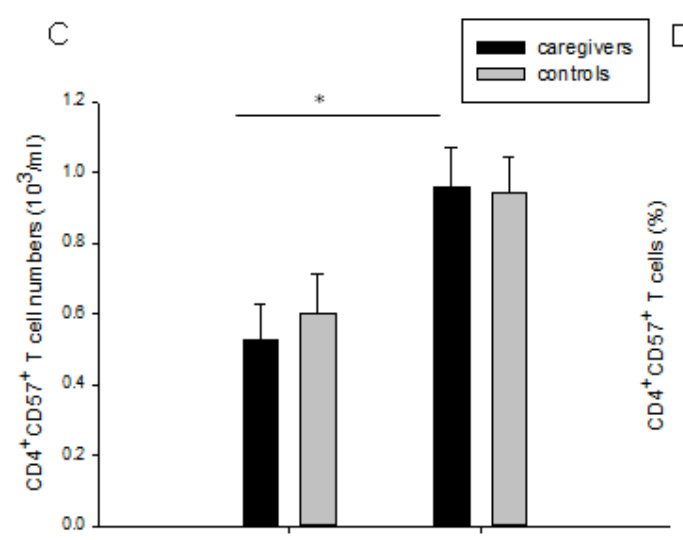
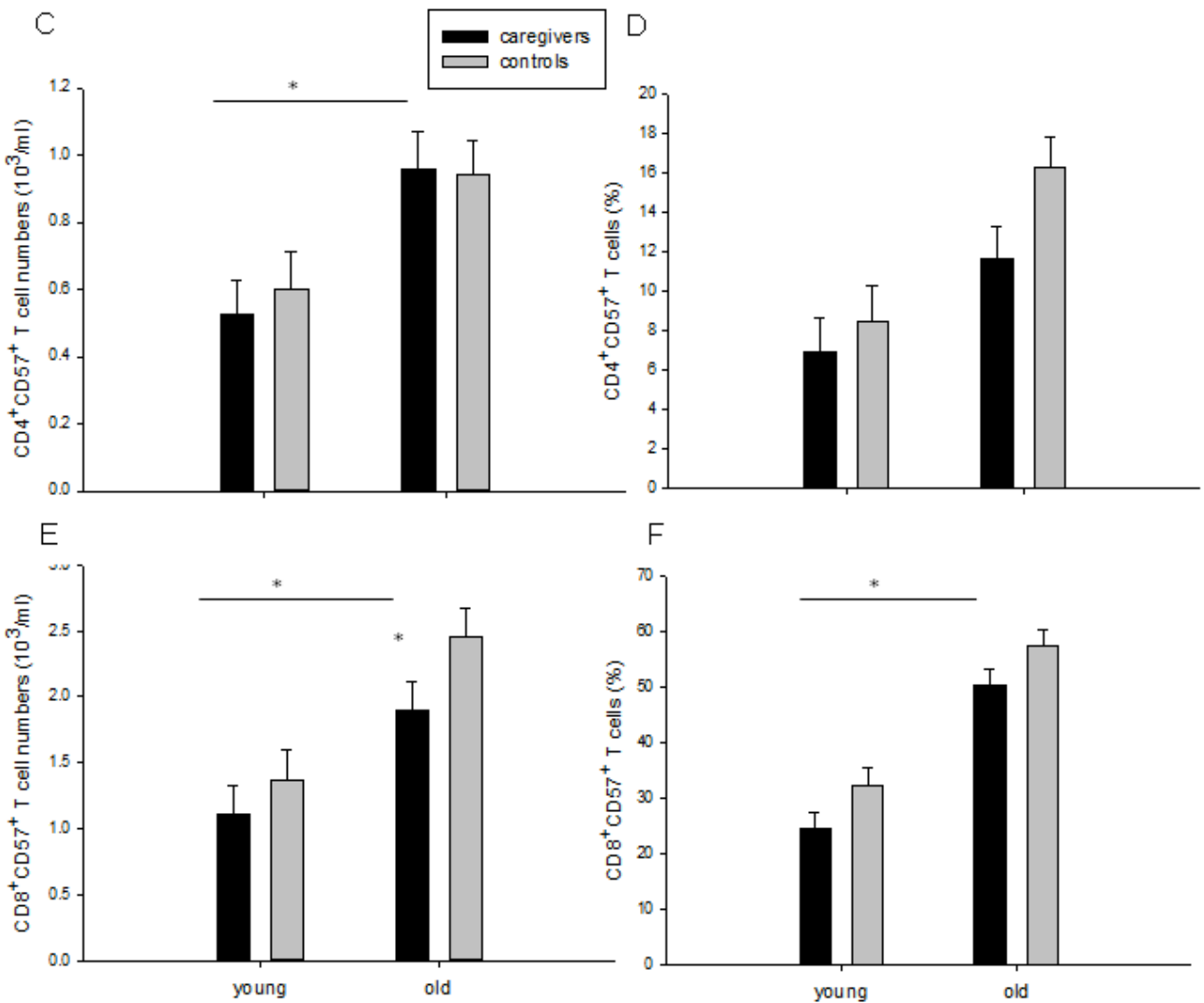

Figure 4. CD3+ cells expressing the CD57 marker of T cell senescence

Representative flow cytometric plots demonstrating gating pattern for identification of: A) CD4+CD57+ cells within a CD3+ cell population of lymphocytes; and B) CD8+CD57+ cells within a CD3+ cell population of lymphocytes. CD4+ CD57+ T cells in old ( $\mathrm{n}=35)$ and young $(n=38)$ caregivers, and old $(n=41)$ and young $(n=31)$ controls, presented in: $C)$ absolute numbers $(103 / \mathrm{ml})$, and $D)$ percentages. $\mathrm{E}$ and $\mathrm{F}$ ) present corresponding histograms for CD8+CD57+ T cells. Data are presented as mean and SEM. * indicates $\mathrm{p}<0.05$. 
A

KLRG1
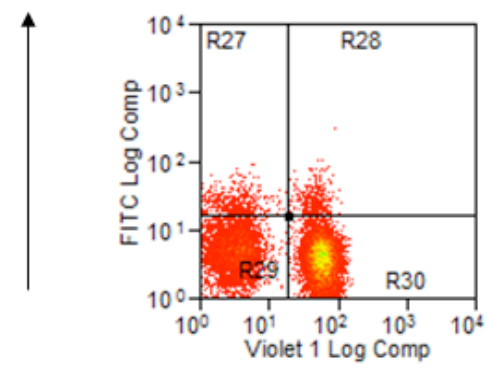

$\mathrm{B}$

KLRG1
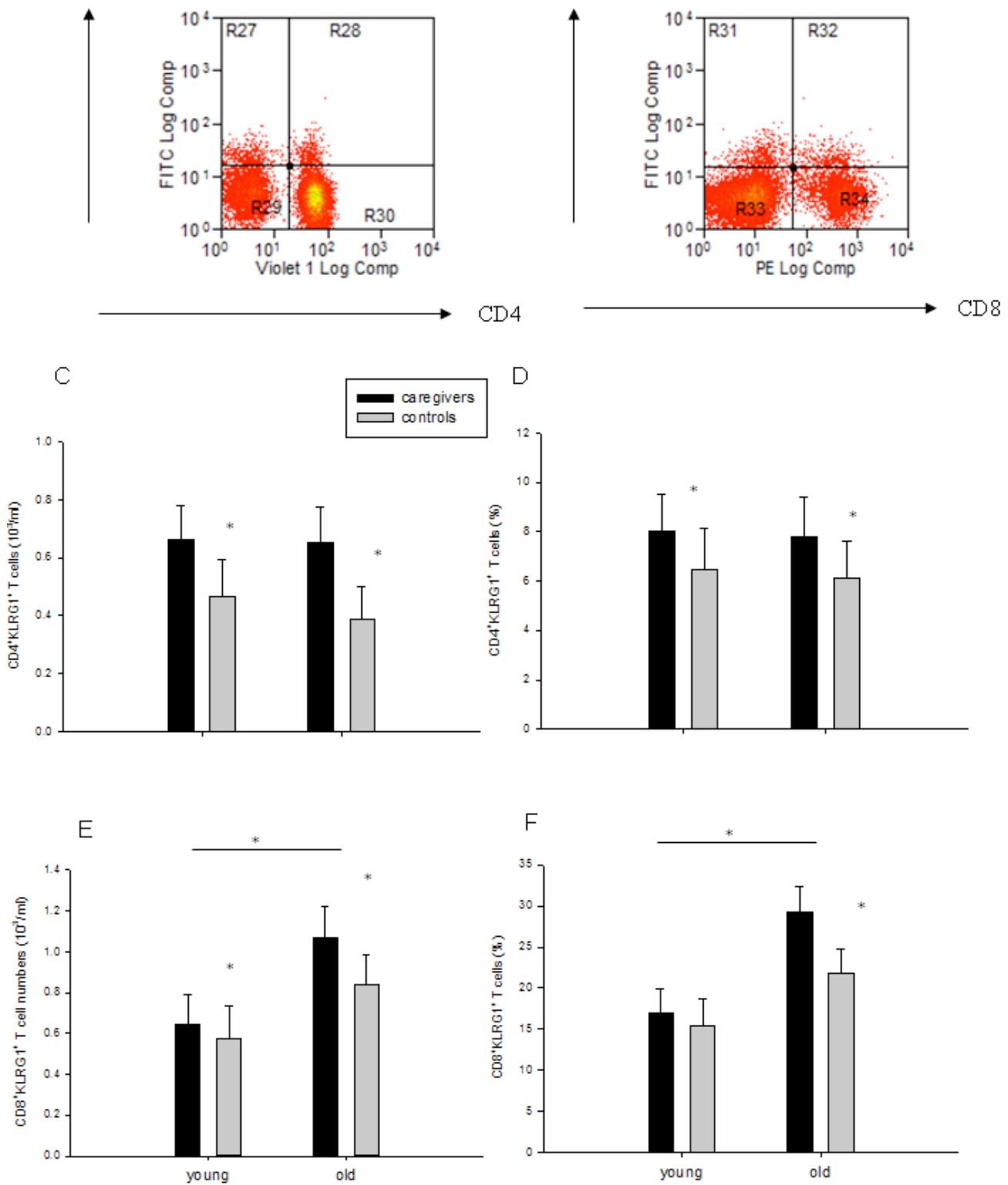

Figure 5. CD3+ cells expressing the KLRG1 marker

Representative flow cytometry describing gating method for detecting: A) CD4+KLRG1+ cells, and B) CD8+KLRG1+ within the population of CD3+ lymphocytes. CD4+KLRG1+ T cells in old $(n=35)$ and young $(n=38)$ caregivers, and old $(n=40)$ and young $(n=31)$ controls, presented in: C) absolute numbers (103/ml), and D) percentages. Under E and F are respective presentations of CD8+KLRG1+ T cells. Data are mean \pm SEM. * indicates $\mathrm{p}<0.05$ 
A

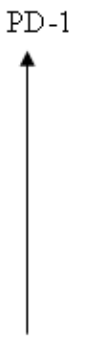

B

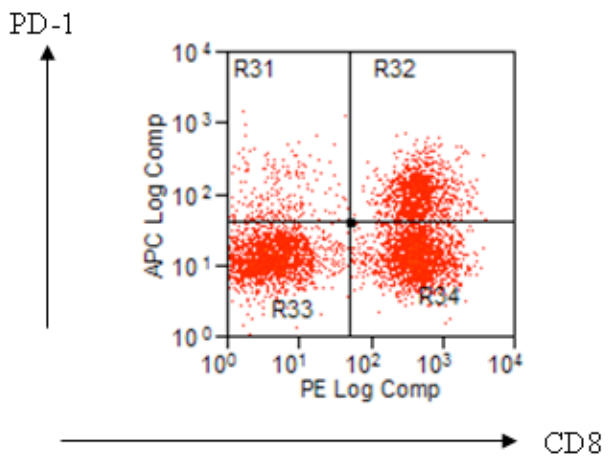

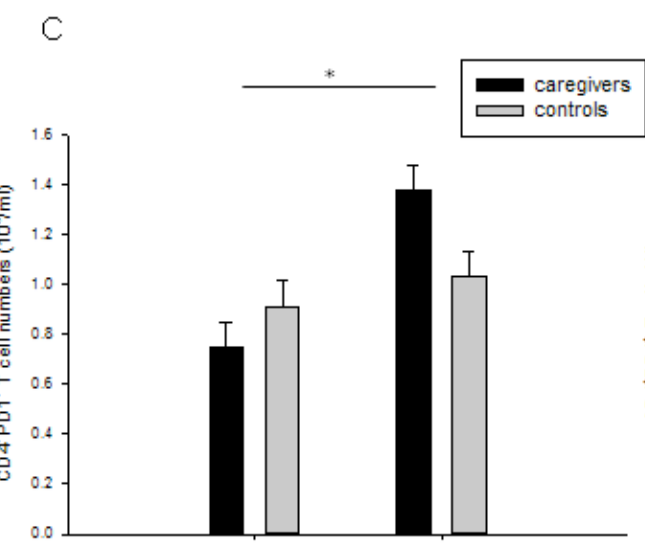

D

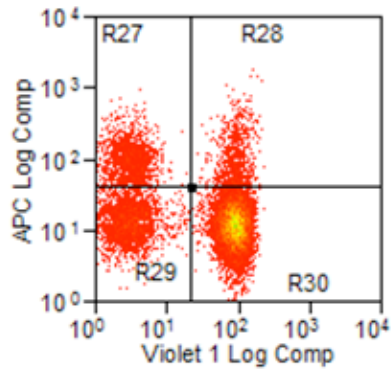

$\mathrm{CD} 4$
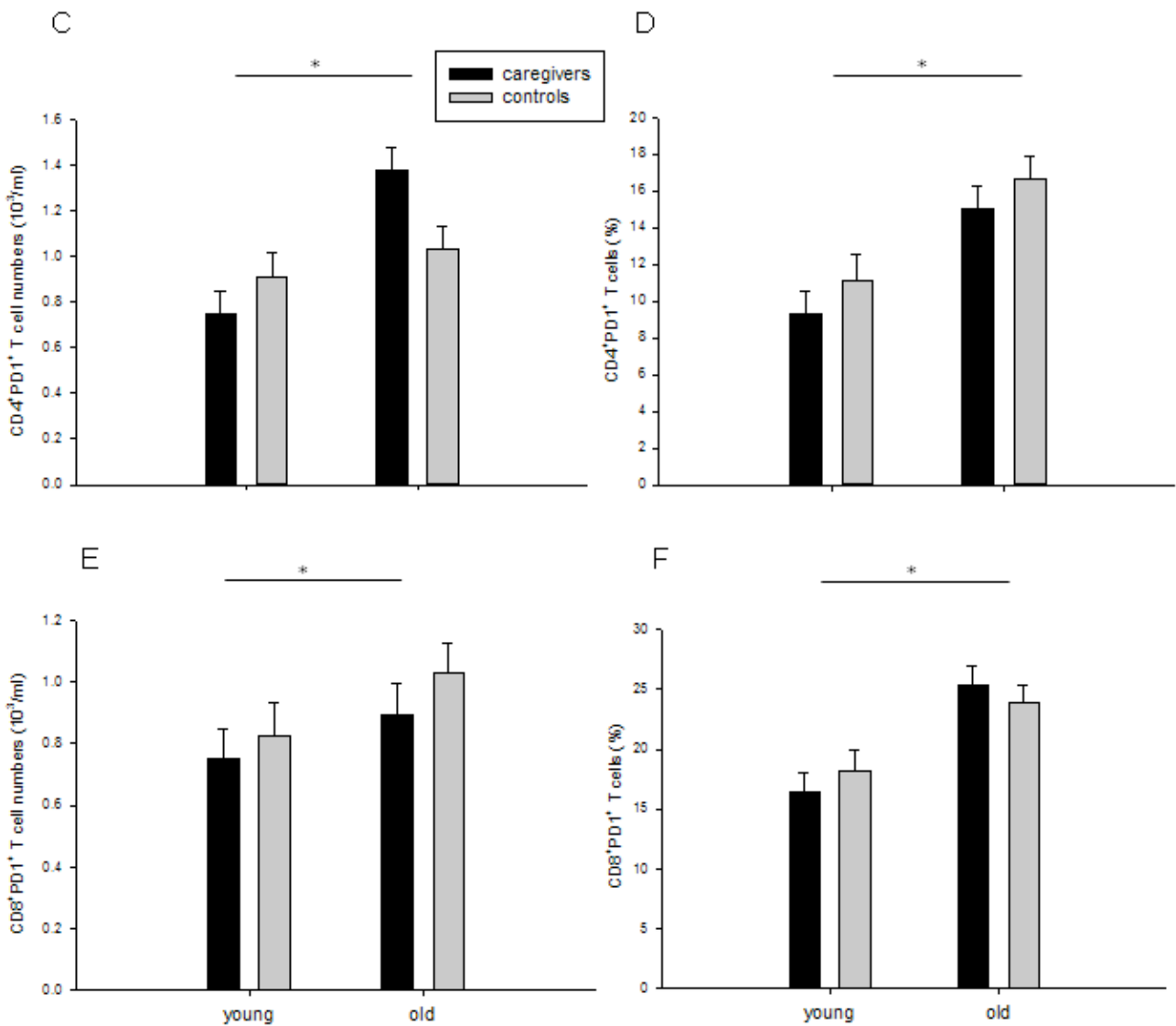

Figure 6. CD $3+$ cells expressing the PD-1 marker of exhaustion

Percentage of T cells showing the expression of PD-1 marker of exhaustion. Representative flow cytometry plot showing gating strategy for detection of: A) CD4+PD-1+, and B) CD8+PD-1+ cells within a CD3+ lymphocyte subset. CD4+PD1+ T cells in old ( $\mathrm{n}=35)$ and young $(n=38)$ caregivers, and old $(n=40)$ and young $(n=31)$ controls, presented as: C) absolute numbers $(103 / \mathrm{ml})$, and $D)$ percentages. $E$ and $\mathrm{F}$ present corresponding values for $\mathrm{CD} 8+\mathrm{PD}-1+\mathrm{T}$ cells. Data are mean $\pm \mathrm{SEM}$. * indicates $\mathrm{p}<0.05$ 
For the number of $\mathrm{CD} 8^{+} \mathrm{PD} 1^{+} \mathrm{T}$ cells (flow cytometry identification shown in Figure 6A), there were no main or interaction effects, but after covariate adjustment a main effect of age emerged $(p=0.02)$ (Figure 6E). For the frequency of these cells, there was a main effect of age $(\mathrm{F}(1,140)=17.72, p<0.001$, $\left.\eta^{2}=0.112\right)$ such that older adults had a higher percentage of $\mathrm{T}$ cells expressing this marker of exhaustion (Figure 6F). This was confirmed in covariate analyses $(p<0.001)$.

\section{TREC levels}

There was a main effect of age on TREC levels $\left(\mathrm{F}(1,139)=109.82, p<0.001, \eta^{2}=0.441\right)$ such that older participants had a greater fold decrease of cells containing TRECs when compared to the calibrator (Figure 7). Covariate adjustment confirmed the main effect of age $(p<0.001)$.

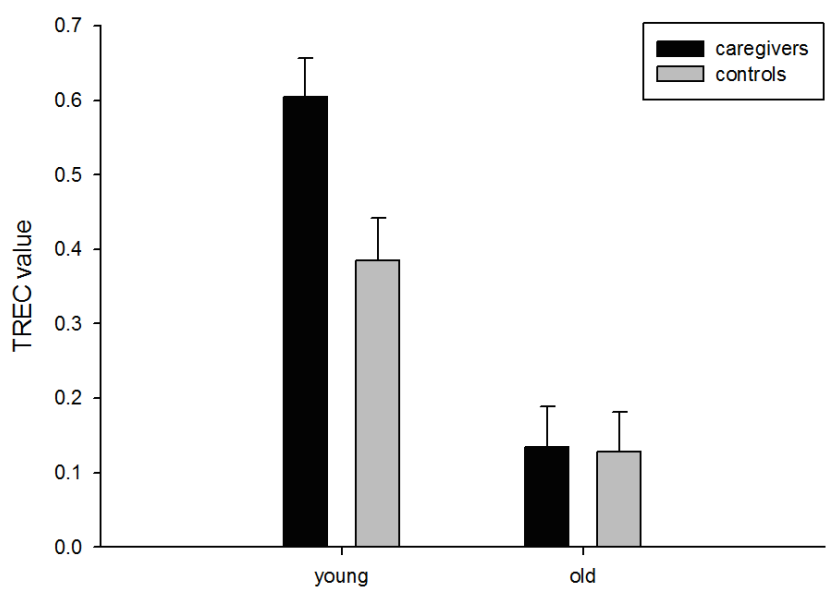

Figure 7. Thymic output presented as T cell receptor excision circles (TREC) expression ratio

Log10 percentage of TREC expression ratio in old $(n=35)$ and young $(n=39)$ caregivers, and old $(n=37)$ and young $(n=32)$ controls. Data are mean \pm SEM. * indicates $\mathrm{p}<0.05$.

\section{CMV seropositivity and serum antibody titre}

Overall, 83 (55\%) participants were CMV-positive, with more CMV-positive participants in the younger group $\left(\chi^{2}(1)=4.91, p=0.03\right)$. In the younger group, 32 $(86 \%)$ were seropositive overall, with caregivers being less likely to be CMV-positive $\left(\chi^{2}(1)=4.43, p=0.04\right)$. In the older group, $51(64 \%)$ participants were CMVpositive, and the incidence of CMV infection was similar between older caregivers and controls $\left(\chi^{2}(1)=0.01, p=0.92\right)$. Within the CMV-positive subset $(n=82)$ for CMV antibody titre, there was no main effect of age, caregiving, or a caregiving $\mathrm{x}$ age interaction.

Analyses of $\mathrm{T}$ cell subsets expressing markers of senescence and exhaustion were re-run, this time controlling for CMV serostatus, to determine if any of the effects observed were driven by CMV infection. All significant main effects of age remained the same, while the caregiving effect for $\mathrm{CD}^{+} \mathrm{CD} 28^{-}(p=0.20)$, $\mathrm{CD}^{+} \mathrm{CD} 28^{+} \quad(p=0.17)$, as well as $\mathrm{CD} 8^{+} \mathrm{CD} 57^{+}$ $(p=0.20)$, disappeared. However, the main effect of caregiving for $\mathrm{T}$ cells expressing KLRG1 remained significant for both $\mathrm{CD}^{+}(p=0.01)$ and $\mathrm{CD}^{+}(p=0.02)$ $\mathrm{T}$ cells.

Finally, median CMV titre was used to split CMVseropositive subjects into two groups, with high vs. low serological responses indicating worse or better viral control. The comparison of $\mathrm{T}$ cell immunity parameters between the groups are presented in Table 2 . Interestingly, the groups were significantly different on almost all immune parameters.

\section{Psychological factors and immune parameters within caregivers in each group}

Within the caregiving group overall, analyses showed that caregivers reporting higher anxiety, depression and stress levels had a lower percentage of $\mathrm{CD} 57^{+}$for both $\mathrm{CD} 4^{+}$and $\mathrm{CD} 8^{+}$, and $\mathrm{CD} 4^{+} \mathrm{PD}-1^{+} \mathrm{T}$ cells, as well as a higher expression ratio of TREC (Table 3). In addition, those with a higher burden index had a lower percentage of $\mathrm{CD}^{+} \mathrm{T}$ cells expressing the PD-1 marker of exhaustion, as well as higher TREC expression (Table 3$)$. 
Table 2. T cell immunity parameters between CMV-seropositive participants with high and low CMV titre, created using median split of CMV titre

\begin{tabular}{|c|c|c|c|}
\hline & $\begin{array}{l}\text { High CMV } \\
\text { titre } \\
\end{array}$ & $\begin{array}{c}\text { Low CMV } \\
\text { titre }\end{array}$ & \\
\hline & \multicolumn{2}{|c|}{ Mean (SD) } & $p$ \\
\hline $\begin{array}{l}\mathrm{CD}^{+}{ }^{+} \mathrm{CD}^{+}{ }^{+} \mathrm{CD} 28^{-} \text {cell } \\
\text { number }\end{array}$ & $1.3(1.23)$ & $1.1(0.73)$ & 0.07 \\
\hline $\begin{array}{l}\mathrm{CD}^{+} \mathrm{CD}^{+} \mathrm{CD}^{+} 8^{-} \\
\text {cells } \%\end{array}$ & $13.5(12.52)$ & $6.1(7.39)$ & $<0.001$ \\
\hline $\begin{array}{l}\mathrm{CD}^{+}{ }^{\mathrm{CD}} 8^{+} \mathrm{CD} 28^{-} \text {cell } \\
\text { number }\end{array}$ & $2.5(1.56)$ & $1.0(0.76)$ & $<0.001$ \\
\hline $\begin{array}{l}\mathrm{CD}^{+}{ }^{+} \mathrm{CD} 8^{+} \mathrm{CD} 28^{-} \\
\text {cells }(\%)\end{array}$ & $57.6(18.39)$ & $35.9(18.23)$ & $<0.001$ \\
\hline $\begin{array}{l}\mathrm{CD} 3^{+} \mathrm{CD} 4^{+} \mathrm{CD} 28^{+} \\
\text {cell number }\end{array}$ & $6.2(2.67)$ & $7.7(2.52)$ & 0.001 \\
\hline $\begin{array}{l}\mathrm{CD} 3^{+} \mathrm{CD} 4^{+} \mathrm{CD} 28^{+} \\
\text {cells }(\%)\end{array}$ & $80.1(15.56)$ & $88.3(8.04)$ & 0.001 \\
\hline $\begin{array}{l}\mathrm{CD} 3^{+} \mathrm{CD} 8^{+} \mathrm{CD} 28^{+} \\
\text {cell number }\end{array}$ & $1.9(1.37)$ & $2.1(1.2)$ & 0.12 \\
\hline $\begin{array}{l}\mathrm{CD}^{+} \mathrm{CD}^{+} \mathrm{CD} 28^{+} \\
\text {cells }(\%)\end{array}$ & $42.3(19.07)$ & $61.5(17.26)$ & $<0.001$ \\
\hline $\begin{array}{l}\mathrm{CD} 3^{+} \mathrm{CD} 4^{+} \mathrm{CD} 57^{+} \\
\text {cell number }\end{array}$ & $1.0(0.71)$ & $0.5(0.47)$ & $<0.001$ \\
\hline $\begin{array}{l}\mathrm{CD}^{+} \mathrm{CD}^{+} \mathrm{CD} 57^{+} \\
\text {cells }(\%)\end{array}$ & $15.8(12.11)$ & $6.5(6.48)$ & $<0.001$ \\
\hline $\begin{array}{l}\mathrm{CD} 3^{+} \mathrm{CD} 8^{+} \mathrm{CD} 57^{+} \\
\text {cell number }\end{array}$ & $2.5(1.56)$ & $1.0(0.76)$ & $<0.001$ \\
\hline $\begin{array}{l}\mathrm{CD}^{+} \mathrm{CD}^{+} \mathrm{CD} 57^{+} \\
\text {cells }(\%)\end{array}$ & $53.5(20.76)$ & $29.9(18.00)$ & $<0.001$ \\
\hline $\begin{array}{l}\mathrm{CD}^{+} \mathrm{CD} 4^{+} \mathrm{KLRG}^{+} \\
\text {cell number }\end{array}$ & $0.6(0.59)$ & $0.5(0.83)$ & 0.01 \\
\hline $\begin{array}{l}\mathrm{CD}^{+}{ }^{+} \mathrm{CD} 4^{+} \mathrm{KLRG}^{+} \\
\text {cells }(\%)\end{array}$ & $8.5(8.61)$ & $5.7(9.95)$ & $<0.001$ \\
\hline $\begin{array}{l}\mathrm{CD}^{+} \mathrm{CD} 8^{+} \mathrm{KLRG}^{+} \\
\text {cell number }\end{array}$ & $1.0(1.14)$ & $0.6(0.56)$ & 0.03 \\
\hline $\begin{array}{l}\mathrm{CD}^{+} \mathrm{CD}^{+} \mathrm{KLRG}^{+} \\
\text {cells }(\%)\end{array}$ & 23.5 (21.59) & $18.4(16.12)$ & 0.43 \\
\hline $\begin{array}{l}\mathrm{CD} 3^{+} \mathrm{CD} 4^{+} \mathrm{PD} 1^{+} \text {cell } \\
\text { number }\end{array}$ & $1.2(0.81)$ & $0.9(0.39)$ & 0.01 \\
\hline $\begin{array}{l}\mathrm{CD}^{+}{ }^{+} \mathrm{CD} 4^{+} \mathrm{PD}^{+} \text {cells } \\
(\%)\end{array}$ & $16.1(9.51)$ & $10.3(5.17)$ & $<0.001$ \\
\hline $\begin{array}{l}\mathrm{CD}^{+}{ }^{+} \mathrm{CD} 8^{+} \mathrm{PD} 1^{+} \text {cell } \\
\text { number }\end{array}$ & $1.0(0.72)$ & $0.8(0.43)$ & 0.25 \\
\hline $\begin{array}{l}\mathrm{CD}^{+}{ }^{+} \mathrm{CD} 8^{+} \mathrm{PD}^{+} \text {cells } \\
(\%)\end{array}$ & $20.0(11.27)$ & $21.9(9.4)$ & 0.10 \\
\hline $\begin{array}{l}\text { TREC expression } \\
\text { ratio }\end{array}$ & $0.3(0.34)$ & $0.4(.41)$ & 0.03 \\
\hline
\end{tabular}

Table 3. Correlations between $T$ cell immunity and caregivers' psychosocial characteristics

\begin{tabular}{|c|c|c|c|c|}
\hline & \multicolumn{4}{|c|}{ Caregivers overall $(n=73)$} \\
\hline & $\begin{array}{c}\mathrm{CD}^{+} \mathrm{CD} 57^{+} \\
(\%)\end{array}$ & $\begin{array}{c}\mathrm{CD}^{+} \mathrm{CD} 57^{+} \\
(\%)\end{array}$ & $\begin{array}{c}\mathrm{CD}^{+}{ }^{+} \mathrm{PD}- \\
1^{+} \\
(\%) \\
\end{array}$ & TREC \\
\hline Anxiety & $\begin{array}{c}-0.25 \\
p=0.04\end{array}$ & ns & $\begin{array}{c}-0.24 \\
p=0.05\end{array}$ & $\begin{array}{c}0.31 \\
p=0.01\end{array}$ \\
\hline Depression & $\begin{array}{c}-0.26 \\
p=0.03\end{array}$ & $\begin{array}{c}-0.24 \\
p=0.04\end{array}$ & $\begin{array}{c}-0.30 \\
p=0.01\end{array}$ & $\begin{array}{c}0.38 \\
p=0.001\end{array}$ \\
\hline $\begin{array}{l}\text { Perceived } \\
\text { stress }\end{array}$ & $\begin{array}{c}-0.30 \\
p=0.01\end{array}$ & $\begin{array}{c}-0.31 \\
p=0.01\end{array}$ & $\begin{array}{c}-0.35 \\
p=0.003\end{array}$ & $\begin{array}{c}0.35 \\
p=0.003\end{array}$ \\
\hline $\begin{array}{l}\text { Caregiver } \\
\text { burden }\end{array}$ & ns & ns & $\begin{array}{c}-0.25 \\
p=0.03\end{array}$ & $\begin{array}{c}0.32 \\
p=0.01\end{array}$ \\
\hline
\end{tabular}

Analysis of the caregiving participants in the younger group showed that young caregivers reporting higher depression, anxiety, perceived stress and burden levels, as well as more problematic behaviour in their child(ren), had higher TREC expression (Table 4). In the older group, caregivers reporting higher problematic behaviour in their spouses/partners had a higher percentage of $\mathrm{CD} 8^{+} \mathrm{CD} 57^{+} \mathrm{T}$ cells (Table 4).

Table 4. Correlations between T cell immunity and young/old caregivers' psychosocial characteristics

\begin{tabular}{lcc}
\hline & $\begin{array}{c}\text { Young } \\
(\mathrm{n}=38)\end{array}$ & $\begin{array}{c}\text { Old } \\
(\mathrm{n}=35)\end{array}$ \\
\hline TREC & $\mathrm{CD}^{+} \mathrm{CD}^{+} 7^{+}$ \\
\hline Anxiety & $-0.34 p=0.04$ & $\mathrm{~ns}$ \\
$\begin{array}{l}\text { Depression } \\
\text { Perceived stress }\end{array}$ & $-0.53 p=0.001$ & $\mathrm{~ns}$ \\
$\begin{array}{l}\text { Caregiver burden } \\
\text { Child behaviour }\end{array}$ & $-0.52 p=0.001$ & $\mathrm{~ns}$ \\
problems (SDQ) & $0.44 p=0.01$ & $\mathrm{~ns}$ \\
$\begin{array}{l}\text { Pearlin problematic } \\
\text { behaviour }\end{array}$ & $0.35 p=0.03$ & - \\
\hline $\mathrm{ns}=$ non-significant & - & $0.42 p=0.02$ \\
\end{tabular}




\section{Discussion}

In the present study we have shown an age-related increase in the absolute number and frequency of the $\mathrm{CD} 8^{+} \mathrm{CD} 28^{-}$subset, but caregivers unexpectedly showed lower numbers of these cells than age- and sex-matched controls, with younger caregivers also having a lower frequency of these cells than younger controls. $\mathrm{CD} 8^{+} \mathrm{CD} 28^{+} \mathrm{T}$ cells predictably showed agerelated changes in the opposite direction, and a caregiving effect in favour of caregivers. While agerelated differences were in agreement with previous reports [8], the apparent positive effect of caregiving was unexpected. The negative impact of $\mathrm{CD} 28^{-} \mathrm{CD} 8 \mathrm{~T}$ cells on immunity is related to their loss of proliferative capacity and a resulting decreased tolerance [35]. The high percentages of CMV- and EBV-specific $\mathrm{CD} 8^{+} \mathrm{CD} 28^{-} \mathrm{T}$ cells in older adults [36] are also thought to compromise immunity by occupying immunological space, leaving limited room for other $\mathrm{T}$ cell subsets to expand when new pathogens are encountered 17]. Accumulation of CD28 $\mathrm{T}$ cells with age has been attributed to repeated antigen stimulation, as $\mathrm{T}$ cell activation induces decreases in CD28 expression through lifelong exposure to pathogens and the constant stimulation by chronic viral infections such as CMV [37]. The present findings confirmed significantly higher numbers of these cells in those with higher CMV antibody titres, but caregivers had a lower incidence of CMV. Therefore, a possible explanation for the lower levels of $\mathrm{CD}^{+} \mathrm{CD} 28^{-} \mathrm{T}$ cells in young caregivers is the significantly lower incidence of chronic CMV infection when compared to the young controls, which would reduce the overall infectious burden responsible for expansion of the $\mathrm{CD} 8^{+} \mathrm{CD} 28^{-} \mathrm{T}$ cell subset [36]. Additional confirmation for this was gained in the repeated analyses using CMV status as covariate, where the caregiving effect disappeared but age remained significant.

As previously reported, in both the $\mathrm{CD} 4^{+}$and $\mathrm{CD} 8^{+}$ subset of $\mathrm{T}$ cells, $\mathrm{CD} 57^{+}$cells were more abundant in the older sample, and this has been related to limited proliferative capacity [10]. On the other hand, the preserved $\mathrm{T}$ cell profile in the case of $\mathrm{CD} 8^{+} \mathrm{CD} 57^{+}$ cells, and lower percentages of $\mathrm{CD} 4^{+} \mathrm{CD} 57^{+}$cells shown among older caregivers was unexpected. However, in the elderly, increased $\mathrm{CD} 57^{+}$cells have previously been related to CMV infection [38]. Although in the present study there was no difference between older caregivers and controls in terms of serum CMV antibody titre, the percentage of $\mathrm{CD} 4{ }^{+} \mathrm{CD} 57^{+} \mathrm{T}$ cells was significantly positively correlated with levels of anti-CMV antibodies (data not shown), which could explain the unexpected increase in the percentage of these cells amongst older controls. This is further confirmed by the significantly higher numbers of these cells among those with a relatively higher CMV antibody titre, and analyses adjusting for CMV status eliminated the caregiving effect. On the other hand, the increase in $\mathrm{CD} 57^{+}$cells in both $\mathrm{CD}^{+}$and $\mathrm{CD}^{+}$subsets, although more prominent in the latter, has been shown to occur after acute exercise, which mobilised these terminally differentiated, highly cytotoxic cells in both young and old [39]. Thus, perhaps the low percentages of these cells in caregivers in the current sample are a dampening of the numbers of cells with high killing potential due to the chronic stress of caregiving. Finally, it has been argued that cells expressing CD57 and/or lacking CD28 represent only terminally differentiated effector $\mathrm{T}$ cells with high cytotoxic potential. These then apoptose after activation, and are therefore not markers of immune deficiency [40].

KLRG-1 was increasingly expressed on $\mathrm{CD}^{+} \mathrm{T}$ cells from the older participants in this study, confirming previous findings [41]. This is not surprising, as this marker of terminally differentiated $T$ cells is associated with replicative senescence and inhibits cell proliferation [41]. In addition, KLRG-1 is known to down-regulate CD95-mediated cell lysis and, in certain cases, inhibit $\mathrm{T}$ cell activation [42]. Interestingly, blockade of this inhibitory marker can restore proliferative function, which indicates the potential involvement of KLRG-1 in exhaustionrelated pathways [41]. Compared to controls, KLRG-1 was also increasingly expressed on both $\mathrm{CD}^{+}$and $\mathrm{CD}^{+} \mathrm{T}$ cells in caregivers, indicating that chronic caregiving stress can affect the functionality of $\mathrm{T}$ cell immunity. This higher percentage of functionally impaired $\mathrm{T}$ cells rich in inhibitory receptors such as KLRG-1 may explain the poorer vaccination response observed in caregivers $[19,21,22]$. It is known that KLRG-1 prevents the response of $\mathrm{CD}^{+} \mathrm{T}$ cells to novel antigens [43] necessary for achieving adequate immune protection following vaccination. Further, 
epigenetic studies lend support for this target-specific effect of caregiving stress on those $T$ cells expressing this senescence marker in caregivers, regardless of their age. Stress through epigenetic changes can impact on immune-related genes via HPA-axis effects [44]. A study of post-traumatic stress disorder showed changes in DNA methylation profiles and gene expression, including KLRG-1, potentially compromising the immunity of stressed individuals [44].

Consistent with most previous research [45], significant age effects were observed for both $\mathrm{CD} 4^{+} \mathrm{PD}-1^{+}$and $\mathrm{CD} 8^{+} \mathrm{PD}-1^{+} \mathrm{T}$ cells, with older adults having a higher percentage of both of these subsets. Chronic caregiving stress did not appear to affect PD1 expression, as caregivers in the current sample showed an exhaustion profile comparable to the controls. Therefore, it seems that although physical stress, such as laparoscopic surgery, can induce an increase in PD-1 expression on T lymphocytes [46], caregiving stress may not affect this aspect of immunity.

The significant age effect on TREC expression was in agreement with previous research, indicating a decrease in thymic output and production of naive $T$ cells with aging [47]. However, no negative effect of caregiving stress was observed; if anything, caregivers showed a trend towards higher thymic output than controls, largely influenced by the younger group.

It was not expected that a higher percentage of CMVpositive individuals would be found in the younger group; the number is higher than previously reported for an equivalent age group [48]. However, since children's CMV infection rates can be high due to day-care centre attendance, this observation could be due to specifically targeting parents [49]. Interestingly, comparison between CMV-seropositive participants with high and low serological profiles revealed group differences in almost all $\mathrm{T}$ cell immunity parameters. This agrees with previous data, which suggest that $\mathrm{CMV}$ drives $\mathrm{T}$ cells towards senesced or exhausted profiles through repeated stimulation in an attempt to control the infection [50].

Higher psychological morbidity was related to lower levels of some immunosenescence markers and higher TREC. This seems counterintuitive, but the overall effect may result from the higher psychological morbidity scores in the group of younger caregivers, who, due to their age, also exhibit the expected lower or absent immunosenescence shown in terms of $\mathrm{T}$ cell marker expression and output of naïve $T$ cells. This is further confirmed by the direct relationship between higher problem behaviours in care-recipients and a higher percentage of $\mathrm{CD} 8^{+} \mathrm{CD} 57^{+} \mathrm{T}$ cells among the older caregivers, and suggests that - for older caregivers at least - future research into caregiving stress should focus on those with higher psychological morbidity.

Overall, these results provide a mixed picture of the effect of caregiving stress on $\mathrm{T}$ cell phenotype in the young and old, with the KLRG1 marker of cell senescence being the main responder to caregiving stress. These data also indicate that the contribution of caregiving stress to immunosenescence is not uniform across $\mathrm{T}$ cell functional markers. The KLRG1 result may indicate that a prominent negative effect of caregiving stress in both young and old would be seen during an active, in vivo immune stimulation/challenge the adaptive immune system, such as vaccination [22]. Caregiving stress in these situations may prevent the immune system from mounting an adequate response. Thus, the higher percentage of KLRG1- $\mathrm{T}$ cells in caregivers and controls presents a potential mechanism for the poorer vaccination responses previously reported in caregivers [43].

This study has a number of limitations. First, the sample size is somewhat small, but it is of the same magnitude as in previous caregiving studies, and large enough to determine the medium effect sizes reported in previous studies. Second, one could argue that participation in the study biased the sample towards those caregivers with lower overall burden and stress levels, and therefore with better immunity. However, attempts were made to avoid this bias by providing home visits for participants. Further, scores on psychosocial scales were comparable if not higher than those in previous research, suggesting that our caregivers did indeed have high burden and stress levels. Finally, staining frozen and thawed PBMCs might have given different results to fresh PBMCs, but as all the samples were treated in the same way, from the moment of blood sampling until data acquisition on the flow cytometer, effects would have been standardised across all groups. 
In conclusion, caregivers showed poorer KLRG-1 T cell profiles compared to controls, but negative effects of caregiving, or an interaction between aging and caregiving stress, were not seen for other markers of $\mathrm{T}$ cell-related immunosenescence and exhaustion. This KLRG-1 effect could explain previous caregiving effects on vaccination response, and suggests KLRG1 as a target for future interventions. Further, among older caregivers, those who reported higher behavioural problems in care recipients showed a greater senescence profile. These findings underline the importance of considering individual differences in the impact of caregiving stress on immunity, and that future research should focus on those reporting higher psychological morbidity.

\section{Acknowledgments}

The authors express their appreciation to Dr Peter Bentham from Birmingham and Solihull Mental Health NHS Foundation, Juniper Centre, Moseley Hall Hospital; and Research Nurses and Support Officers from Lincolnshire, North Staffordshire and Bradford District Care NHS Trust for their outstanding help with the recruitment process. Further thanks are due to Dr Jennifer Heaney, Dr Rebecca Randell, Dr Sarah Jackman, and Dr Jane Upton for their help in collecting samples on syndrome group days, as well as Jusnara Begum from Cancer Sciences, University of Birmingham, for her help with CMV ELISA. Special thanks are also extended to all the study participants.

\section{References}

1. Powell ND, Allen RG, Hufnagle AR, Sheridan JF, Bailey MT. Stressor-induced alterations of adaptive immunity to vaccination and viral pathogens. Immunol Allergy Clin North Am. 2011;31(1):69-79.

2. Gallagher S, Phillips AC, Drayson MT, Carroll D. Parental caregivers of children with developmental disabilities mount a poor antibody response to pneumococcal vaccination. Brain Behav Immun. 2009;23(3):338-46.

3. Pariante CM, Carpiniello B, Orru MG, Sitzia R, Piras A, Farci AMG, et al. Chronic caregiving stress alters peripheral blood immune parameters: The role of age and severity of stress. Psychother Psychosom. 1997;66(4):199-207.
4. Selye H. The stress of life. New York, NY, USA: McGraw-Hill; 1956.

5. Fagnoni FF, Vescovini R, Passeri G, Bologna G, Pedrazzoni M, Lavagetto $G$, et al. Shortage of circulating naive $\mathrm{CD} 8(+) \mathrm{T}$ cells provides new insights on immunodeficiency in aging. Blood. 2000;95(9):2860-8.

6. Pawelec G. Immunosenescence comes of age Symposium on aging research in immunology: The impact of genomics. Embo Reports. 2007;8(3):220-3.

7. Kong FK, Chen CLH, Cooper MD. Thymic function can be accurately monitored by the level of recent $\mathrm{T}$ cell emigrants in the circulation. Immunity. 1998;8(1):97104.

8. Boucher N, Dufeu-Duchesne T, Vicaut E, Farge D, Effros RB, Schachter F. CD28 expression in T cell aging and human longevity. Exp Gerontol. 1998;33(3):26782.

9. McNerlan SE, Rea IM, Alexander HD, Morris TC. Changes in natural killer cells, the CD57CD8 subset, and related cytokines in healthy aging. J Clin Immunol. 1998;18(1):31-8.

10. Brenchley JM, Karandikar NJ, Betts MR, Ambrozak DR, Hill BJ, Crotty LE, et al. Expression of CD57 defines replicative senescence and antigen-induced apoptotic death of $\mathrm{CD} 8+\mathrm{T}$ cells. Blood. 2003;101(7):2711-20.

11. Focosi D, Bestagno M, Burrone O, Petrini M. CD57+ T lymphocytes and functional immune deficiency. J Leukoc Biol. 2010;87(1):107-16.

12. Wherry EJ. $T$ cell exhaustion. Nat Immunol. 2011;12(6):492-9.

13. Lages CS, Lewkowich I, Sproles A, Wills-Karp M, Chougnet C. Partial restoration of T-cell function in aged mice by in vitro blockade of the PD-1/ PD-L1 pathway. Aging Cell. 2010;9(5):785-98.

14. Grundemann C, Bauer M, Schweier O, von Oppen N, Lassing U, Saudan P, et al. Cutting edge: identification of E-cadherin as a ligand for the murine killer cell lectin-like receptor G1. J Immunol. 2006;176(3):13115 .

15. Vasto S, Colonna-Romano G, Larbi A, Wikby A, Caruso C, Pawelec G. Role of persistent CMV infection in configuring $\mathrm{T}$ cell immunity in the elderly. Immun Ageing. 2007;4:2.

16. Akbar AN, Henson SM. Are senescence and exhaustion intertwined or unrelated processes that compromise immunity? Nat Rev Immunol. 2011;11(4):289-95.

17. Pawelec G, Akbar A, Caruso C, Solana R, GrubeckLoebenstein B, Wikby A. Human immunosenescence: is it infectious? Immunol Rev. 2005;205:257-68.

18. Chidrawar S, Khan N, Wei W, McLarnon A, Smith N, Nayak L, et al. Cytomegalovirus-seropositivity has a profound influence on the magnitude of major lymphoid subsets within healthy individuals. Clin Exp Immunol. 2009;155(3):423--32. 
19. Kiecolt-Glaser JK, Glaser R, Gravenstein S, Malarkey WB, Sheridan J. Chronic stress alters the immune response to influenza virus vaccine in older adults. Proc Natl Acad Sci USA. 1996;93(7):3043-7.

20. Glaser R, Kiecolt-Glaser JK. Chronic stress modulates the virus-specific immune response to latent herpes simplex virus type 1. Ann Behav Med. 1997;19(2):7882.

21. Vedhara K, Cox NKM, Wilcock GK, Perks P, Hunt M, Anderson S, et al. Chronic stress in elderly carers of dementia patients and antibody response to influenza vaccination. Lancet. 1999;353(9153):627-31.

22. Gallagher S, Phillips AC, Drayson MT, Carroll D. Caregiving for children with developmental disabilities is associated with a poor antibody response to influenza vaccination. Psychosom Med. 2009;71(3):341-4.

23. Marmot MG, Smith GD, Stansfeld S, Patel C, North F, Head $\mathrm{J}$, et al. Health inequalities among British civil cervants - The Whitehall II study. Lancet. 1991;337(8754):1387-93.

24. Zigmond AS, Snaith RP. The hospital anxiety and depression scale. Acta Psychiatr Scand. 1983;67(6):36170 .

25. Cohen S, Kamarck T, Mermelstein R. A global measure of perceived stress. J Health Soc Behav. 1983;24(4):385-96.

26. Bedard M, Molloy DW, Squire L, Dubois S, Lever JA, O'Donnell M. The Zarit Burden Interview: A new short version and screening version. Gerontologist. 2001;41(5):652-7.

27. Dunst C, Trivette C, Deal A. Enabling and empowering families: principles and guidelines for practice. Cambridge, MA, USA: Brookline Books; 1988.

28. Goodman R. The Strengths and Difficulties Questionnaire: a research note. J Child Psychol Psychiatry. 1997;38(5):581-6.

29. Pearlin LI, Mullan JT, Semple SJ, Skaff MM. Caregiving and the stress process: an overview of concepts and their measures. Gerontologist. 1990;30(5):583-94.

30. Douek DC, McFarland RD, Keiser PH, Gage EA, Massey JM, Haynes BF, et al. Changes in thymic function with age and during the treatment of HIV infection. Nature. 1998;396(6712):690-5.

31. Hazenberg MD, Verschuren MC, Hamann D, Miedema F, van Dongen JJ. T cell receptor excision circles as markers for recent thymic emigrants: basic aspects, technical approach, and guidelines for interpretation. $\mathrm{J}$ Mol Med. 2001;79(11):631-40.

32. Pfaffl MW. A new mathematical model for relative quantification in real-time RT-PCR. Nucleic Acids Res. 2001;29(9):e45.

33. Savva GM, Pachnio A, Kaul B, Morgan K, Huppert FA, Brayne C, et al. Cytomegalovirus infection is associated with increased mortality in the older population. Aging Cell. 2013;12(3):381-7.
34. Roepke SK, Mausbach BT, Aschbacher K, Ziegler MG, Dimsdale JE, Mills PJ, et al. Personal mastery is associated with reduced sympathetic arousal in stressed Alzheimer caregivers. Am J Geriatr Psychiatry. 2008;16(4):310-7.

35. Bour-Jordan $\mathrm{H}$, Esensten JH, Martinez-Llordella $\mathrm{M}$, Penaranda C, Stumpf M, Bluestone JA. Intrinsic and extrinsic control of peripheral T-cell tolerance by costimulatory molecules of the CD28/ B7 family. Immunol Rev. 2011;241(1):180-205.

36. Weng NP, Akbar AN, Goronzy J. CD28(-) T cells: their role in the age-associated decline of immune function. Trends Immunol. 2009;30(7):306-12.

37. Vallejo AN. CD28 extinction in human T cells: altered functions and the program of T-cell senescence. Immunol Rev. 2005;205:158-69.

38. Pourgheysari B, Khan N, Best D, Bruton R, Nayak L, Moss PA. The cytomegalovirus-specific CD4+ T-cell response expands with age and markedly alters the CD4+ T-cell repertoire. J Virol. 2007;81(14):7759-65.

39. Simpson RJ, Florida-James GD, Cosgrove C, Whyte GP, Macrae S, Pircher H, et al. High-intensity exercise elicits the mobilization of senescent $\mathrm{T}$ lymphocytes into the peripheral blood compartment in human subjects. J Appl Physiol. 2007;103(1):396-401.

40. Kern F, Ode-Hakim S, Vogt K, Hoflich C, Reinke P, Volk HD. The enigma of CD57+CD28- $\mathrm{T}$ cell expansion--anergy or activation? Clin Exp Immunol. 1996;104(1):180-4.

41. Henson SM, Franzese O, Macaulay R, Libri V, Azevedo RI, Kiani-Alikhan $\mathrm{S}$, et al. KLRG1 signaling induces defective Akt (ser473) phosphorylation and proliferative dysfunction of highly differentiated CD $8+\mathrm{T}$ cells. Blood. 2009;113(26):6619-28.

42. Rosshart S, Hofmann M, Schweier O, Pfaff AK, Yoshimoto K, Takeuchi T, et al. Interaction of KLRG1 with E-cadherin: new functional and structural insights. Eur J Immunol. 2008;38(12):3354-64.

43. Shi L, Wang JM, Ren JP, Cheng YQ, Ying RS, Wu XY, et al. KLRG1 impairs CD4+ $\mathrm{T}$ cell responses via p16ink4a and p27kip1 pathways: role in hepatitis B vaccine failure in individuals with hepatitis $\mathrm{C}$ virus infection. J Immunol. 2014;192(2):649-57.

44. Uddin M, Aiello AE, Wildman DE, Koenen KC, Pawelec G, de Los Santos R, et al. Epigenetic and immune function profiles associated with posttraumatic stress disorder. Proc Natl Acad Sci USA. 2010;107(20):9470-5.

45. Lefebvre JS, Haynes L. Aging of the CD4 T cell compartment. Open Longev Sci. 2012;6:83-91.

46. Arai Y, Saito H, Ikeguchi M. Upregulation of TIM-3 and PD-1 on CD4+ and CD8+ T cells associated with dysfunction of cell-mediated immunity after colorectal cancer operation. Yonago Acta Med. 2012;55(1):1-9. 
47. Naylor K, Li G, Vallejo AN, Lee WW, Koetz K, Bryl E, et al. The influence of age on T cell generation and TCR diversity. J Immunol. 2005;174(11):7446-52.

48. Staras SA, Dollard SC, Radford KW, Flanders WD, Pass RF, Cannon MJ. Seroprevalence of cytomegalovirus infection in the United States, 1988-1994. Clinical infectious diseases: an official publication of the Infectious Diseases Society of America. 2006;43(9):1143-51.

49. Adler SP. Molecular epidemiology of cytomegalovirus: viral transmission among children attending a day care center, their parents, and caretakers. J Pediatr. 1988;112(3):366--72.

50. Almanzar G, Schwaiger S, Jenewein B, Keller M, Herndler-Brandstetter D, Wurzner R, et al. Long-term cytomegalovirus infection leads to significant changes in the composition of the CD8(+) T-cell repertoire, which may be the basis for an imbalance in the cytokine production profile in elderly persons. J Virol. 2005;79(6):3675-83. 